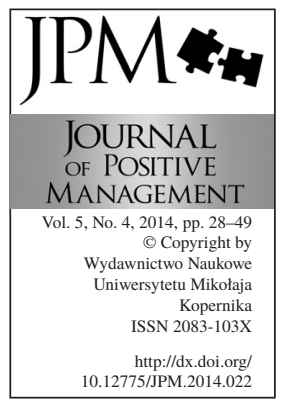

\title{
THE ROLE OF LEADERSHIP IN SHAPING INTERPERSONAL RELATIONSHIPS IN THE CONTEXT OF POSITIVE ORGANIZATIONAL POTENTIAL
}

\author{
Andrzej Lis ${ }^{\mathrm{a}}$, Aldona Glińska-Neweś ${ }^{\mathrm{b}}$, \\ Magdalena Kalińska ${ }^{\text {c }}$
}

The Faculty of Economic Sciences and Management, Nicolaus

Copernicus University, Toruń, Poland

a e-mail: andrzejlis@econ.umk.pl

be-mail: ajka@econ.umk.pl

c email: kalinska@econ.umk.pl

\begin{abstract}
Research purpose: The aim of the paper is to analyze the role of leadership in shaping interpersonal relationships in the context of Positive Organizational Potential. In order to achieve our aim, the three following research objectives have been set: (1) to assess the influence of intra-organizational antecedents related to leadership on interpersonal relationships, (2) to identify and analyze the correlations between top management behaviors and interpersonal relationships considered as the key areas of Positive Organizational Potential, and (3) to identify and analyze the correlations between middle management behaviors and interpersonal relationships considered as the key areas of Positive Organizational Potential.
\end{abstract}

Methodology/approach: The analyses are based on the findings of the questionnaire survey conducted in companies operating in Poland and the Delphi panel grouping researchers and business practitioners.

Findings: Leadership-related factors are identified as a category of intra-organizational antecedents of a strong impact on interpersonal relationships. Such findings are confirmed for the majority of studied intra-organizational antecedents related to leadership including: leaders' ability to influence and inspire others, models of relationships provided by both the top and middle managers, leaders' emphatic behaviors, treating subordinates with respect and building the climate of trust. The study of correlations between the key areas of Positive Organizational Potential confirms that interpersonal relationships are much strongly correlated with the attitudes and behaviors of middle managers than with those of top managers.

Limitations/implications: The small number of firms participating in the survey $(\mathrm{N}=73)$ and the fact that the research sample included only companies operating in Poland should be considered as limitations to extend the findings and conclusions to a wider population. 
Originality/value: The paper is based on the findings of empirical research including a questionnaire survey and a Delphi panel. It makes references and is the extension of works by Glińska-Neweś (2013) and Haffer (2013) based on the same empirical material. The added value of the paper is the thoroughness of the study and its increased objectivity being the result of combining various data elicitation techniques.

Keywords: Positive Organizational Scholarship, Positive Organizational Potential, leadership, top managers, middle managers, interpersonal relationships.

Paper type: Research paper

\section{Introduction}

Positive Organizational Potential (POP) refers to such a state and characteristics of company resources that create positive, development-supporting employee behaviors with an intermediary of positive organizational climate and culture (Glińska-Neweś, 2010, p. 46). The concept of Positive Organizational Potential combines the assumptions of Positive Organizational Scholarship (POS) and Resource Based View (RBV). The first project of our research team concerning Positive Organizational Potential, conducted between 2008 and 2010, revealed particularly strong correlations among some areas of positive potential (Stankiewicz, 2010), including leadership shaping POP (Karaszewski, 2010). Therefore, in the following study, conducted between 2011 and 2013, we explored in more detail the following key areas of Positive Organizational Potential: corporate governance, leadership (top managers), middle managers, talent management, interpersonal relationships, trust, language of internal communication, organizational citizenship behaviors and corporate social responsibility (Stankiewicz, 2013a). As regards the issue of leadership we made a distinction between top managers (Karaszewski and Lis, 2013) and middle managers (Kalińska, 2013b) due to the differences in their roles played in organizations and their influence on organizational culture and organizational climate.

Discussing the mechanisms governing Positive Organizational Potential, Haffer (2013, pp. 308-309) measures the influence of management quality (including top management and middle management considered as the POP key areas) on remaining key areas, including interpersonal relationships. His findings based on the regression analysis point out that the attitudes and behaviors of middle managers are a much stronger determinant of interpersonal relationships than the leadership skills of top managers. Moreover, Glińska-Neweś (2013, pp. 140-142) identifies and discusses intra-organizational factors related to leadership as important antecedents of interpersonal-relationships. The aforementioned studies indicate that the influence of leadership on interpersonal-relationships is an interesting field of investigation which should be explored in a more detailed way. 
THE ROLE OF LEADERSHIP IN SHAPING

Andrzej Lis

Aldona Glińska-Neweś

Magdalena Kalińska
Therefore, the aim of the paper is to analyze the role of leadership in shaping interpersonal relationships in the context of Positive Organizational Potential. In order to achieve the aim, the three following research objectives have been set: (1) to assess the influence of intra-organizational antecedents related to leadership on interpersonal relationships, (2) to identify and analyze the correlations between top management behaviors and interpersonal relationships considered as the key areas of Positive Organizational Potential, and (3) to identify and analyze the correlations between middle management behaviors and interpersonal relationships considered as the key areas of Positive Organizational Potential.

The paper is based on data collected within the research project entitled "Strategic management of the key areas of Positive Organizational Potential determinants, solutions and models recommended for companies operating in Poland". The project was funded by the National Science Center research grant number DEC-2011/01/B/HS4/00835. The questionnaire survey in the companies operating in Poland and the Delphi method were main data elicitation techniques used to collect data necessary for analyses.

The paper consists of introduction, three chapters and conclusions. The first chapter presenting the literature review is divided in three sections concerning: the concept of Positive Organizational Potential, interpersonal relationships and the role played by top and middle managers in shaping relationships within an organization and working teams. The second chapter describes research methods and the procedure of the study. The third chapter provides the analysis and discussion of statistical data. The empirical chapter consists of two sections. Section one studies the influence of intra-organizational antecedents related to leadership on interpersonal relationships. The analyses included into section one are the extension of studies by Glińska-Neweś (2013, pp. 139-142) validated by the opinions of the participants of the Delphi panel. Section two identifies and discusses correlations between the key areas of Positive Organizational Potential: top management behaviors and interpersonal relationships and then between middle management behaviors and interpersonal relationships.

\section{Literature review}

\subsection{Positive Organizational Potential}

The term Positive Organizational Potential (POP) was introduced by Stankiewicz (2010) and his associates including two authors of this paper. The idea and assumptions of Positive Organizational Potential were particularly inspired by Positive Organizational Scholarship (POS) considered as an umbrella concept covering theories aimed at the analysis of positive organizational deviations. Scholars integrated within this domain, as they declare, are mainly interested in: 
- "the study of especially positive outcomes, processes, and attributes of organizations and their members" (Cameron et al., 2003, p. 4);

- "an emphasis on identifying individual and collective strengths (attributes and processes) and discovering how such strengths enable human flourishing (goodness, generativity, growth, and resilience)" (Roberts, 2006, p. 292);

- "the states and processes that arise from and result in life-giving dynamics, optimal functioning, and enhanced capabilities and strengths" (Dutton and Glynn, 2007, p. 693).

Positive Organizational Scholarship varies from other management concepts and theories by three biases expressed in its name. Positive stands for the focus on "positive outcomes, processes, and attributes of organizations and their members". Organizational means that the approach is interested in states and processes in the organizational context. Scholarship denotes a scientific rigor in exploring the field of study (Cameron et al., 2003, pp. 4-6). The adjective 'positive' is the most controversial in the concept. For this reason some scholars accuse POS to be naïve or even dangerous (Ehrenreich, 2009). In fact, 'positive' refers in this case to an alternative, strength-building perspective of organizational problems. Furthermore, it means a focus on extraordinarily positive outcomes or positively deviant performance that dramatically exceed common or expected performance (Cameron and Spreitzer, 2012).

Resource Based View was the other source of inspiration for the Positive Organizational Potential concept. In previous projects our research team studied the role of resources as antecedents of company competitive advantage and its business performance (Stankiewicz, 1999; Stankiewicz, 2002). Therefore, combining the two aforementioned research perspectives we identified the construct of Positive Organizational Potential. POP refers to such a state and characteristics of company resources that create positive, developmentsupporting employee behaviors with an intermediary of positive organizational climate and culture (Glińska-Neweś, 2010, p. 46; Peyrat-Guillard and GlińskaNeweś, 2010, pp. 50-51). The concept of Positive Organizational Scholarship is built on a few assumptions which combine a resource-based approach with a positive paradigm. First of all, we treat employee behaviors as a key determinant of company development while these behaviors are mainly influenced by the company resources configuration. Secondly, we focus our attention on positive behaviors which we consider with POS concept lens. Thus, these behaviors may be categorized into following groups: behaviors manifesting employee emphasis on strengths rather than weaknesses, manifesting their positive relationships and trust, openness and creativeness. 
THE ROLE

OF LEADERSHIP IN SHAPING

Andrzej Lis

Aldona Glińska-Neweś

Magdalena Kalińska

\subsection{Interpersonal relationships in the POS context}

Relationships are the essence of the organization life. While completing their tasks employees build their attachments, connections and bonds. At the same time interpersonal relationships affect what one can think, feel and do (Blustein, 2011; Kahn, 2007, p. 189). Relationships serve as a prism through which an employee perceives his or her work and an organizational environment. Taking this into account, it is worth to consider the meaning of high quality and positivity of relationships at work. Although they are rather difficult to define unambiguously, some measures are proposed. Thus, positive relationships are considered with regard to their strength (Mills and Clark, 1982), emotional weight of an attachment (Kahn, 1998), affective weight, mutuality and frequency of communication (Granovetter, 1973), or subjective experiences of vitality and aliveness, positive regard, mutuality and positive physiological reactions (Stephens et al., 2012). Dutton and Heaphy (2003) equate positive relationships with high-quality connections. Their quality is relevant to a nature of connective tissue between relationship partners. If it is lifegiving, the connection will be elastic, strong, resilient, vital. Corrosive connections are life-depleting and destructive.

Positive relationships at work receive increasing attention in business studies. They are regarded as stimulators of positive attitude to work and employee wellbeing, and restraints of employee overloading (Ragins and Dutton, 2007; Grant and Parker, 2009). They provide employees with a higher sense of meaningfulness, safety and availability (Kahn, 1998). Employees are more willing to invest their energy in organizational citizenship behaviors (Chiaburu and Harrison, 2008). As the result, various positive effects for the organization performance are reported, such as effective knowledge management (Ibarra, 1993; Gersick et al., 2000), creativity (Atwater and Carmeli, 2009), job satisfaction and commitment (Halbesleben, 2012), and decrease in absence and employee turnover (Chiaburu and Harrison, 2008).

Generally, the ties that bind employees may vary from instrumental to friendship ties. Positive relationships may be considered in a more detailed way with a use of the following dimensions (Allen and Turner de Tormes, 2012; Glińska-Neweś, 2013, pp. 132-134):

- affective tone which means the degree of positive emotions within a relationship. Teams with a stronger affective tone are characterized by bigger enthusiasm, excitement and warmth;

- emotional carrying capacity referring to the extent to which a relationship covers and endures a range of various positive and negative emotions (Ragins and Dutton, 2007). Positive relationships are able to sustain in the face of multiplicity of different emotions;

- tensility is the extent to which a relationship can bend and endure strain in the face of challenges and setbacks (Dutton and Heaphy, 2003). A 
greater degree of tensility allows employees to express authentic emotions without the fear of interpersonal consequences;

- interdependence manifests itself in frequency, strength and span of mutual influence;

- intimacy consists of self-disclosure and partner responsiveness. Greater intimacy is connected with divulging more emotionally charged information of a highly personal nature;

- permanence reflects the degree that a relationship is stable and obligatory.

The aforementioned relationships dimensions provided a foundation for the identification of variables used in the questionnaire survey.

\subsection{The roles of top and middle managers in shaping interpersonal relationships}

The role of leadership in shaping interpersonal relationships has received much of the attention in the literature. Leader interaction style has been considered as an interesting research subject for many years. The first studies in this domain conducted at the Ohio State University distinguished between leader behaviors initiating structure and those oriented to consideration (Stogdill, 1974). Studies by the researchers at the University of Michigan, identified two types of leadership behaviors: employee orientation and production orientation. Both aforementioned studies highlighted dichotomy between task-and relationship- oriented leadership styles. Since then many interpersonal and social exchange theories of leadership have been dominated by this way of thinking. For instance, Fiedler's (1964) contingency theory tried to match leaders to appropriate situations. The most favorable situations are those characterized by good leader-follower relations, defined tasks, and a strong leader's position power.

Transformational theory of leadership is possibly the most endorsed leadership framework which has investigated the social exchange and interpersonal dynamics of leaders and followers (Bass, 1985, 1996; Bass and Avolio, 1990, 1993). The model describes how different kinds of leader behaviors and interactions between leaders and followers empower the followers. Among other models, Fiedler (1964) treats the overall quality of this relationship as a key situational moderator. Vroom and Yetton (1973) prescribe the circumstances that allow for a greater or smaller degree of follower participation in the leader's decision making process. Dansereau et al. (1975) and Graen and Uhl-Bien (1998) describe how leader-subordinate dynamics vary across individuals and subgroups of followers. The relational leadership theory considers the relational dynamics (the social processes) that comprise leadership and organizing. The theory perceives leadership as the process by which social systems change through the structuring of roles and relationships (Uhl-Bien, 2003, 2005). All the theories mentioned above have been quite successful in defining a number of potential variables and processes that characterize effective leadership. 
THE ROLE OF LEADERSHIP IN SHAPING

Andrzej Lis

Aldona Glińska-Neweś

Magdalena Kalińska
However, these models have not applied a multilevel approach to leadership, assuming that the process of leadership is relatively similar at all organizational echelons. Effective leadership is not limited to the heads of organizations or to one best way of leading (Bass, 1990) and it does not automatically reside in a single, often heroic, individual.

From a POS perspective leadership is a process, a system, that has a very broad range and depth (Avolio, 2011). There are many actors in this system and they all are correlated with each other by many relationships. Positive leadership approaches are defined by their focus on positive capabilities that can be measured, developed and which lead to performance improvement, and by the inclusion of the positive organizational context that leaders foster (Luthans and Church, 2002). From a POS perspective, leaders can play an important role in enabling extraordinary performance through positively deviant behaviors. It is not just to create positive emotions in people. Positively deviant leadership places an emphasis on "what elevates individuals and organizations (in addition to what challenges them), what goes right in organizations (in addition to what goes wrong), what is life-giving (in addition to what is problematic or life-depleting), what is experienced as good (in addition to what is objectionable), what is extraordinary (in additions to what is merely effective), and what is inspiring (in addition to what is difficult or arduous)". Positively deviant leadership is associated with the promotion of outcomes such as interpersonal flourishing, meaningful work, virtuous behaviors, positive emotions, and energizing networks (Cameron, 2012, p. 2).

Both top and middle managers have an important influence on interpersonal relationships but they play different roles (Kalińska, 2013a). Top leaders are those who formulate and articulate the strategic moves of an organization (Eisenhardt et al., 1997), they make decisions that set the course of an organization, whereas middle management interprets and executes those decisions (Floyd and Wooldridge, 1997; Guth and MacMillan, 1986). CEOs have the power to shape the path of organization and possess the tools to create and change the structure and culture within an organization. They influence main directions and "set agenda" of an organization. Middle managers operate directly below the top managers and perform much of day-to-day work within an organization. They are responsible for making many trade-offs that shape the company's success. Which echelon of managers is more influential from the perspective of interpersonal relationships? this is an interesting research question. With this paper we aim to contribute to social exchange and interpersonal dynamics of a leader and their followers by providing a more broad mechanism by which both CEOs and middle managers contribute to the company performance by influencing positive relationships among subordinates. 


\section{Research method}

Data elicitation techniques included the questionnaire survey conducted in companies operating in Poland and the Delphi panel grouping both researchers and business practitioners.

The questionnaire survey was conducted in the second half of 2012. In the first step, paper questionnaires were distributed to the CEOs of top 500 companies operating in Poland. In the second step, around 5000 companies were invited via e-mail to participate in the survey. Generally, companies were very reluctant to take in part in the study. Despite the efforts of the research team, only 73 firms contributed to the survey. In consequence, the small number of firms participating in the survey and the fact that the research sample included only companies operating in Poland should be considered as limitations to extend the findings and conclusions to a wider population.

The respondents represented the following industries: extracting and manufacturing companies - 28 (34.8\%), trade companies - 9 (12.3\%), construction companies $-7(9.6 \%)$, service industry $-18(24.7 \%)$, energy production and distribution $-8(11.0 \%)$, financial services and banking sector $-2(2.7 \%)$ and 1 IT company $(1.3 \%)$. There were $40(54.8 \%)$ big companies (more than 250 employees) and 29 (39.7\%) small and medium enterprises (SMEs). 4 companies provided no data concerning their size.

The reliability of the questionnaire was confirmed by calculating Cronbach alpha coefficients (values from 0.83 to 0.97 ) for 21 aggregated variables including: the key areas of Positive Organizational Potential (9 variables), the groups of intraorganizational antecedents of Positive Organizational Potential (10 variables) and the manifestations of company development and performance ( 2 variables). The following values of the coefficient were calculated for the variables analyzed in this paper:

- intra-organizational antecedents related to leadership - 0.90;

- key areas of Positive Organizational Potential: leadership (top managers) -0.93 , middle managers -0.94 , interpersonal relationships -0.93 .

The questionnaires were addressed to top managers (CEOs) of the surveyed companies. The task of the respondents was to assess the state of Positive Organizational Potential manifestations in their companies as well as the intraorganizational antecedents of POP. All the variables were positive statements describing the states of company resources and their antecedents. The respondents provided the assessment of Positive Organizational Potential in their companies using the scale from $0 \%$ ("I totally disagree") to $100 \%$ ("I totally agree").

The Delphi session was conducted in September 2012, in Toruń. The panel of experts consisted of 5 researchers [1] within the fields considered as the key areas of Positive Organizational Potential and 8 business practitioners [2]. Similarly to the questionnaire survey, the participants of the Delphi panel assessed, among 
THE ROLE OF LEADERSHIP IN SHAPING

Andrzej Lis

Aldona Glińska-Neweś

Magdalena Kalińska other issues, the influence of the intra-organizational antecedents (including those related to leadership) on shaping ideal (desired) states of the key areas of Positive Organizational Potential (including interpersonal relationships). The six grade scale $<0,1,2, \ldots, 5\rangle$ was used for assessment $(0-$ referred to lack of impact, 1 -very little impact, 2 - little impact, 3 - moderate impact, 4 - high impact, 5 - very high impact).

In order to operationalize the empirical survey the research team defined the ideal (desired) states of the key areas of Positive Organizational Potential and enumerated their manifestations. The questionnaire included 53 manifestations of Positive Organizational Potential grouped in key areas such as: corporate governance, leadership (top managers), middle managers, talent management, interpersonal relations, trust, language of internal communication, organizational citizenship behaviors and corporate social responsibility.

The desirable state of interpersonal relationships means that the relationships among employees are based on positive attitudes and emotions such as: friendliness, sympathy, respect, acceptance and trust relating to their engagement in building-up a common value system and achieving common aims (Stankiewicz, 2013b, p. 318). The following manifestations of interpersonal relationships considered as a key area of Positive Organizational Potential were identified:

- employees can count on each other;

- employees show interest in each other;

- employees are frank with each other;

- employees like each other;

- employees show acceptance and they respect each other;

- interpersonal relationships within working teams contribute to relationships among the teams in the company.

Ideal leadership is an art of encouraging employee engagement and their willingness to undertake initiatives to achieve ambitious goals, expectations and aspirations. Such leadership is based on authority, knowledge, competencies, social sensitivity and the leader's vision (Stankiewicz, 2013b, p. 318). The following manifestations of leadership considered as a key area of Positive Organizational Potential were identified:

- CEO directs employees in accordance with their competencies and s/he stimulates them intellectually;

- CEO inspires employees with his/her vision;

- CEO is a charismatic and conscientious person eager to take up challenges and showing initiative and engagement;

- CEO inspires employee trust;

- CEO is oriented to their co-worker satisfaction.

Desirable middle level managers are people of high personal, emotional and social competencies. They interpret and implement the decisions of top executives. 
They perform the function of ambassadors between top management and workers as well as between the teams in a company. They are 'glue' uniting a company (Stankiewicz, 2013b, p. 318). The following manifestations of middle managers behaviors and attitudes considered as a key area of Positive Organizational Potential were identified:

- managers perform leadership roles in their teams;

- managers coordinate their teams and foster relations;

- managers perform coaching roles in their teams;

- managers capture and disseminate information on business goals and objectives;

- managers initiate changes in a company;

- through their behaviors, mangers set a good example of positive relations both within and outside the team;

- managers are oriented to self-development and increasing their skills and competencies.

The catalogue of the POP intra-organizational antecedents in the questionnaire consisted of 89 factors related to tangible resources, organizational strategy, structure, internal communication, innovation, control, human resources management, power and democratization of management, integration and employee identification with the company and leadership. The research team identified the following intra-organizational antecedents of the Positive Organizational Potential development related to leadership:

- the top management provides a positive model of relations with employees;

- the middle management provides a positive model of relations with employees;

- supervisors are able to influence and inspire others;

- supervisors behave emphatically;

- supervisors treat others with respect;

- the chairperson of the supervisory board has appropriate experience, character, knowledge, interpersonal skills, teamworking skills;

- a person of unquestionable skills and competencies is appointed to the position of a CEO;

- supervisors strengthen trust and the climate of justice.

\section{Analysis and discussion}

\subsection{Leaders' behaviors as antecedents of interpersonal relationships}

The study of the influence of intra-organizational antecedents on the key areas of Positive Organizational Potential was one of the objectives of the questionnaire survey. The respondents evaluated 89 determinants categorized in 
THE ROLE

OF LEADERSHIP IN SHAPING

Andrzej Lis Aldona Glińska-Neweś Magdalena Kalińska

Table 1.

Correlations between aggregated intraorganizational antecedents of the Positive Organizational Potential development and the manifestations of interpersonal relationships
10 groups related to: tangible resources, strategy, organizational structure, internal communication, innovation, control, human resources management, power and democratization of management, integration and employee identification with the company and leadership. In order to assess the strength of relations between the aggregated intra-organizational antecedents and interpersonal relationships, the correlations between these variables were analyzed (Table 1).

\begin{tabular}{|c|c|c|c|c|c|c|c|c|c|c|}
\hline \multirow{2}{*}{$\begin{array}{l}\text { Interpersonal } \\
\text { relationships } \\
\text { and their } \\
\text { manifestations }\end{array}$} & \multicolumn{10}{|c|}{ Intra-organizational antecedents } \\
\hline & 1 & 2 & 3 & 4 & 5 & 6 & 7 & 8 & 9 & 10 \\
\hline $\begin{array}{l}\text { Interpersonal } \\
\text { relationships }\end{array}$ & $0.613^{* *}$ & $0.635^{* *}$ & $0.585^{* *}$ & $0.688^{* *}$ & $0.552^{* *}$ & $0.578^{* *}$ & $0.628^{* *}$ & $0.571^{* *}$ & $0.670^{* *}$ & $0.726^{* *}$ \\
\hline $\begin{array}{l}\text { Employees can count } \\
\text { on each other }\end{array}$ & $0.582^{* *}$ & $0.549^{* *}$ & $0.516^{* *}$ & $0.611^{* *}$ & $0.454^{* *}$ & $0.500^{* *}$ & $0.611^{* *}$ & $0.501^{* *}$ & $0.637^{* *}$ & $0.643^{* *}$ \\
\hline $\begin{array}{l}\text { Employees show } \\
\text { interest in each other }\end{array}$ & $0.566^{* *}$ & $0.494^{* *}$ & $0.514^{* *}$ & $0.581^{* *}$ & $0.422^{* *}$ & $0.516^{* *}$ & $0.512^{* *}$ & $0.469^{* *}$ & $0.558^{* * *}$ & $0.662^{* * *}$ \\
\hline $\begin{array}{l}\text { Employees are frank } \\
\text { with each other }\end{array}$ & $0.570^{* * *}$ & $0.577^{* *}$ & $0.533^{\text {** }}$ & $0.666^{* * *}$ & $0.490^{* *}$ & $0.587^{* *}$ & $0.521^{* *}$ & $0.549^{* *}$ & $0.635^{* *}$ & $0.641^{* *}$ \\
\hline $\begin{array}{l}\text { Employees like each } \\
\text { other }\end{array}$ & $0.430^{* *}$ & $0.543^{* *}$ & $0.486^{* *}$ & $0.559^{* *}$ & $0.468^{* *}$ & $0.485^{* *}$ & $0.440^{* *}$ & $0.468^{* * *}$ & $0.510^{* *}$ & $0.559^{* *}$ \\
\hline $\begin{array}{l}\text { Employees show } \\
\text { acceptance and they } \\
\text { respect each other }\end{array}$ & $0.495^{* *}$ & $0.519^{* * *}$ & $0.512^{* *}$ & $0.592^{* *}$ & $0.488^{* *}$ & $0.502^{* *}$ & $0.469^{* *}$ & $0.452^{* * *}$ & $0.497^{* *}$ & $0.671^{\text {*** }}$ \\
\hline
\end{tabular}

Interpersonal

relationships

within working

teams contribute to $0.507^{* *} 0.590^{* *} 0.469^{* *} 0.547^{* *} 0.537^{* *} 0.405^{* *} 0.655^{* *} 0.501^{\text {** }} 0.599^{\text {** }} 0.586^{\text {** }}$ relationships among

the teams in the

company

1 - tangible resources; 2 - strategy; 3 - organizational structure; 4 - internal communication; 5 - innovation; 6 - control; 7 - Human Resources Management; 8 - power and democratization of management; 9 - integration and employee identification with the company; 10 - leadership.

$\mathrm{N}=73$, Pearson correlation coefficient, $* *$ correlation significant at level of 0.01 ; $*$ correlation significant at level of 0.05

The leadership-related factors were identified as the strongest correlates of interpersonal relationships among all the groups of intra-organizational antecedents (Pearson correlation coefficient $r=0.726$ ). Moreover, they were found to be the most strongly correlated in the case of 4 out of 6 manifestations of interpersonal relationships such as: "employees can count on each other" $(r=0.643)$, "employees show interest in each other" $(r=0.662)$, "employees like each other" $(r=0.559)$, "employees show acceptance and they respect each other" 
$(r=0.671)$. In one case ("employees are frank with each other"), the leadershiprelated factors were the second among the ten groups of intra-organizational determinants (correlation $r=0.641$ ).

In order to validate the findings of the questionnaire study, we analyzed the opinions of experts participating in the Delphi panel. Their estimations (arithmetic means) of the influence the groups of intra-organizational antecedents of Positive Organizational Potential have on interpersonal relationships (considered as a POP key area) are presented in Table 2 . The variables included into each category of POP intra-organizational antecedents are enumerated by Karaszewski and Lis (2014).

\begin{tabular}{lccccccccccc}
\hline \multirow{2}{*}{ Variables } & \multicolumn{1}{c}{ Intra-organizational antecedents of Positive Organisational Potential } \\
\cline { 2 - 11 } & $\mathbf{1}$ & $\mathbf{2}$ & $\mathbf{3}$ & $\mathbf{4}$ & $\mathbf{5}$ & $\mathbf{6}$ & $\mathbf{7}$ & $\mathbf{8}$ & $\mathbf{9}$ & $\mathbf{1 0}$ \\
\hline $\begin{array}{l}\text { interpersonal } \\
\text { relationships }\end{array}$ & 2.72 & 2.93 & 3.44 & 3.78 & 2.83 & 3.00 & 3.41 & 2.43 & 3.21 & 3.72 \\
\hline
\end{tabular}

1 - tangible resources; 2 - strategy; 3 - organizational structure; 4 - internal communication; 5 - innovation; 6 - control; 7 - Human Resources Management; 8 - power and democratization of management; 9 - integration and employee identification with the company; 10 - leadership.

The assessment scale $\langle 0,1,2, \ldots, 5\rangle$. The categories of the scale refer to: 0 - lack of impact, 1 - very little impact, 2 - little impact, 3 - moderate impact, 4 - high impact, 5 - very high impact.

According to the experts, the majority of the categories of POP intraorganizational antecedents have moderate impact on interpersonal relationships considered as a key area of Positive Organizational Potential. The antecedents related to internal communication and leadership were assessed as those of the strongest influence on interpersonal relationships which confirmed the results of the questionnaire research discussed above and earlier studies by Glińska-Neweś (2013, pp. 139-143).

Recognizing the key role of the leadership-related factors among intraorganizational antecedents of interpersonal relationships, the correlations between these two variables were studied in detail (Table 3, Glińska-Neweś, 2013, pp. 141).

As regards the aggregated construct of interpersonal relationships, significant correlations (above $r=0.500$ ) were noticed in 6 out of 8 intra-organizational antecedents related to leadership. The supervisors' ability to influence and inspire others was the identified as the most strongly correlated variable $(r=0.709)$. Moreover, strong correlations were observed between interpersonal relationships and antecedents related to models of relations provided by both the top and middle managers, leaders' emphatic behaviors, treating subordinates with respect and building the climate of trust. Contrary, the requirements concerning knowledge, skills and competencies of a CEO and a chairperson of the 
THE ROLE

OF LEADERSHIP

IN SHAPING

Andrzej Lis

Aldona Glińska-Neweś

Magdalena Kalińska

Table 3.

Correlations between intra-organizational antecedents of the Positive Organizational

Potential development related to leadership and the manifestations of interpersonal relationships

\begin{tabular}{|c|c|c|c|c|c|c|c|c|}
\hline \multirow{2}{*}{$\begin{array}{l}\text { Interpersonal relationships } \\
\text { and their manifestations }\end{array}$} & \multicolumn{8}{|c|}{ Intra-organizational antecedents related to leadership } \\
\hline & 1 & 2 & 3 & 4 & 5 & 6 & 7 & 8 \\
\hline Interpersonal relationships & $0.613^{* *}$ & $0.686^{* *}$ & $0.709^{* *}$ & $0.686^{* *}$ & $0.592^{* *}$ & $0.331^{* *}$ & $0.334^{* *}$ & $0.676^{* *}$ \\
\hline $\begin{array}{l}\text { Employees can count on each } \\
\text { other }\end{array}$ & $0.611^{* *}$ & $0.691^{* *}$ & $0.574^{* *}$ & $0.645^{* *}$ & $0.405^{* *}$ & 0.202 & $0.337^{* *}$ & $0.578^{* *}$ \\
\hline $\begin{array}{l}\text { Employees show interest in } \\
\text { each other }\end{array}$ & $0.530^{* *}$ & $0.655^{* *}$ & $0.753^{* *}$ & $0.627^{* *}$ & $0.543^{* *}$ & $0.275^{*}$ & 0.228 & $0.586^{* *}$ \\
\hline $\begin{array}{l}\text { Employees are frank with } \\
\text { each other }\end{array}$ & $0.533^{* *}$ & $0.543^{* *}$ & $0.644^{* *}$ & $0.621^{* *}$ & $0.539^{* *}$ & $0.351^{* *}$ & 0.236 & $0.581^{* *}$ \\
\hline Employees like each other & $0.380^{* *}$ & $0.444^{* *}$ & $0.640^{* *}$ & $0.501^{* *}$ & $0.574^{* *}$ & $0.314^{* *}$ & 0.190 & $0.550^{* *}$ \\
\hline $\begin{array}{l}\text { Employees show } \\
\text { acceptance and they respect } \\
\text { each other }\end{array}$ & $0.505^{* *}$ & $0.532^{* *}$ & $0.719^{* *}$ & $0.592^{* *}$ & $0.711^{* *}$ & $0.355^{* *}$ & 0.215 & $0.697^{* *}$ \\
\hline $\begin{array}{l}\text { Interpersonal relationships } \\
\text { within working teams contri- } \\
\text { bute to relationships among } \\
\text { the teams in the company }\end{array}$ & $0.583^{* *}$ & $0.658^{* *}$ & $0.400^{* *}$ & $0.552^{* *}$ & $0.301^{*}$ & $0.248^{*}$ & $0.483^{* *}$ & $0.533^{* *}$ \\
\hline $\begin{array}{l}1 \text { - the top management provi } \\
\text { ment provides a positive mod } \\
\text { inspire others; } 4 \text {-supervisors } \\
\text { irperson of the supervisory bo } \\
\text { teamworking skills; } 7 \text { - a pers } \\
\text { of a CEO; } 8 \text { - supervisors stre }\end{array}$ & $\begin{array}{l}\text { of relat } \\
\text { have en } \\
\text { has ap } \\
\text { of unq }\end{array}$ & $\begin{array}{l}\text { tions with } \\
\text { nphatical } \\
\text { opropriate } \\
\text { uestionab } \\
\text { ist and the }\end{array}$ & $\begin{array}{l}\text { y; } 5 \text { - sup } \\
\text { experien } \\
\text { le skills } \\
\text { e climate }\end{array}$ & $\begin{array}{l}\text { of } 3-\mathrm{s} \\
\text { and comp } \\
\text { of justice }\end{array}$ & $\begin{array}{l}\text { upervisor } \\
\text { treat othe } \\
\text { cter, knov } \\
\text { etencies }\end{array}$ & app & $\begin{array}{l}\text { to in } \\
\text { pect; } \\
\text { erper } \\
\text { ed to }\end{array}$ & $\begin{array}{l}\text { nanage- } \\
\text { nce and } \\
\text { the cha- } \\
\text { al skills, } \\
\text { position }\end{array}$ \\
\hline $\begin{array}{l}\mathrm{N}=73 \text {, Pearson correlation } \mathrm{cc} \\
\text { at level of } 0.05\end{array}$ & icient, & $*$ corre & tion sig & ficant & evel of 0 . & $1 ; * \operatorname{cor} 1$ & relation $\mathrm{s}$ & ignificant \\
\hline
\end{tabular}

supervisory board appeared to be less significantly correlated with interpersonal relationships.

Similar patterns of correlations were valid for the majority of the interpersonal relationships manifestations. Only in two cases some differences were observed. As regards to friendship ("employees like each other") the correlations with the models of managers' relations were weaker in comparison with other antecedents. In case of extending positive team relationships ("interpersonal relationships within working teams contribute to relationships among the teams in the company"), managers' ability to influence others and treating them with respect were found to be less correlated.

Similarly to the procedure applied above, the findings of the questionnaire survey were compared and validated by the analysis of the opinions expressed by the experts participating in the Delphi panel (Table 4).

According to the expert opinions, the majority of the antecedents of Positive Organizational Potential related to leadership have a high impact on interpersonal relationship considered as a key area of POP. The only exceptions (arithmetic 


\begin{tabular}{lcccccccc}
\hline \multirow{2}{*}{ Variables } & \multicolumn{8}{c}{ Intra-organizational antecedents related to leadership } \\
\cline { 2 - 9 } & $\mathbf{1}$ & $\mathbf{2}$ & $\mathbf{3}$ & $\mathbf{4}$ & $\mathbf{5}$ & $\mathbf{6}$ & $\mathbf{7}$ & $\mathbf{8}$ \\
\hline $\begin{array}{l}\text { Interpersonal } \\
\text { relationships }\end{array}$ & 3.78 & 3.89 & 3.89 & 4.33 & 4.33 & 2.44 & 2.89 & 4.22 \\
\hline
\end{tabular}

1 - the top management provides a positive model of relations with employees; 2 - the middle management provides a positive model of relations with employees; 3 - supervisors are able to influence and inspire others; 4 - supervisors behave emphatically; 5 - supervisors treat others with respect; 6 - the chairperson of the supervisory board has appropriate experience, character, knowledge, interpersonal skills, teamworking skills; 7 - a person of unquestionable skills and competencies is appointed to the position of a CEO; 8 - supervisors strengthen trust and the climate of justice.

The assessment scale $<0,1,2, \ldots, 5>$. The categories of the scale refer to: 0 - lack of impact, 1 - very little impact, 2 - little impact, 3 - moderate impact, 4 - high impact, 5 - very high impact.

mean below 3.00) include the competencies of the board chairperson and the chief executive officer. The managerial behaviors of the strongest impact on interpersonal relationships are: empathy, treating other people with respect and building trust and proper atmosphere in a company.

\subsection{Correlations between the key areas of Positive Organizational Potential}

Positive Organizational Potential includes the following key areas: corporate governance, leadership, middle managers, talent management, interpersonal relations, trust, the language of internal communication, organizational citizenship behaviors and corporate social responsibility. It is assumed that Positive Organizational Potential generates the synergy effect. Therefore, the correlations between its key areas were analyzed (Table 5, Haffer, 2013, p. 304). The correlations of interpersonal relationships with leadership and middle managers were highlighted.

First of all it should be stressed that Positive Organizational Potential is a very consistent construct. All the correlations between its key areas are relatively strong. They range from $r=0.454$ (between corporate governance and organizational citizenship behaviors) to $r=0.835$ (between trust and organizational citizenship behaviors). The mutual interactions between the key areas of Positive Organizational Potential are studied in detail by Haffer (2013, pp. 304-309).

The analysis of correlations in Table 5 shows that middle managers are the second strongest correlate $(r=0.745)$ of interpersonal relationships while top managers (leadership) are the second weakest factor $(r=0.554)$ in pair with them. In order to explore in details the tendencies identified above, we conducted the analyses of correlations between the manifestations of interpersonal relationships and the manifestations of leadership and middle managers' behaviors (Table 6 and Table 7). 
THE ROLE

OF LEADERSHIP IN SHAPING

Andrzej Lis Aldona Glińska-Neweś Magdalena Kalińska

Table 5.

Correlations between the key areas of Positive Organizational Potential

\begin{tabular}{|c|c|c|c|c|c|c|c|c|}
\hline Variable & 1 & 2 & 3 & 4 & 5 & 6 & 7 & 8 \\
\hline \multicolumn{9}{|l|}{ 1. Corporate governance } \\
\hline 2. Leadership & $0.563^{* *}$ & & & & & & & \\
\hline 3. Middle managers & $0.481^{* *}$ & $0.612^{* *}$ & & & & & & \\
\hline 4. Talent management & $0.520^{* *}$ & $0.476^{* *}$ & $0.672^{* *}$ & & & & & \\
\hline 5. Interpersonal relationships & $0.547^{* *}$ & $0.554^{* *}$ & $0.745^{* *}$ & $0.721^{* *}$ & & & & \\
\hline 6. Trust & $0.527^{* *}$ & $0.736^{* *}$ & $0.739^{* *}$ & $0.685^{* *}$ & $0.832^{* * *}$ & & & \\
\hline $\begin{array}{l}\text { 7. Intra-organizational commu- } \\
\text { nication }\end{array}$ & $0.552^{* *}$ & $0.640^{* *}$ & $0.657^{* *}$ & $0.707^{* *}$ & $0.628^{* *}$ & $0.761^{* *}$ & & \\
\hline $\begin{array}{l}\text { 8. Organizational citizenship } \\
\text { behaviors }\end{array}$ & $0.454^{* *}$ & $0.640^{* *}$ & $0.664^{* *}$ & $0.553^{* *}$ & $0.738^{* *}$ & $0.835^{* *}$ & $0.660^{* *}$ & \\
\hline $\begin{array}{l}\text { 9. Corporate social responsi- } \\
\text { bility }\end{array}$ & $0.632^{* *}$ & $0.620^{* *}$ & $0.678^{* *}$ & $0.757^{* *}$ & $0.628^{* *}$ & $0.673^{* *}$ & $0.770^{* *}$ & $0.569^{* *}$ \\
\hline
\end{tabular}

$\mathrm{N}=73$, Pearson correlation coefficient, $* *$ correlation significant at level of 0.01 ; * correlation significant at level of 0.05

\begin{tabular}{lllllllllll}
\hline Variable & 1 & 2 & 3 & 4 & 5 & 6 & 7 & 8 & 9 & 10 \\
\hline
\end{tabular}

1. CEO directs employees in accordance with their competencies and $\mathrm{s} / \mathrm{he}$ stimulates them intellectually

2. CEO inspires employees with his/her vision $0.916^{* *}$

3. CEO is a charismatic and conscientious person eager to take up challenges and sho- $0.750^{* *} 0.769^{* *}$ wing initiative and engagement

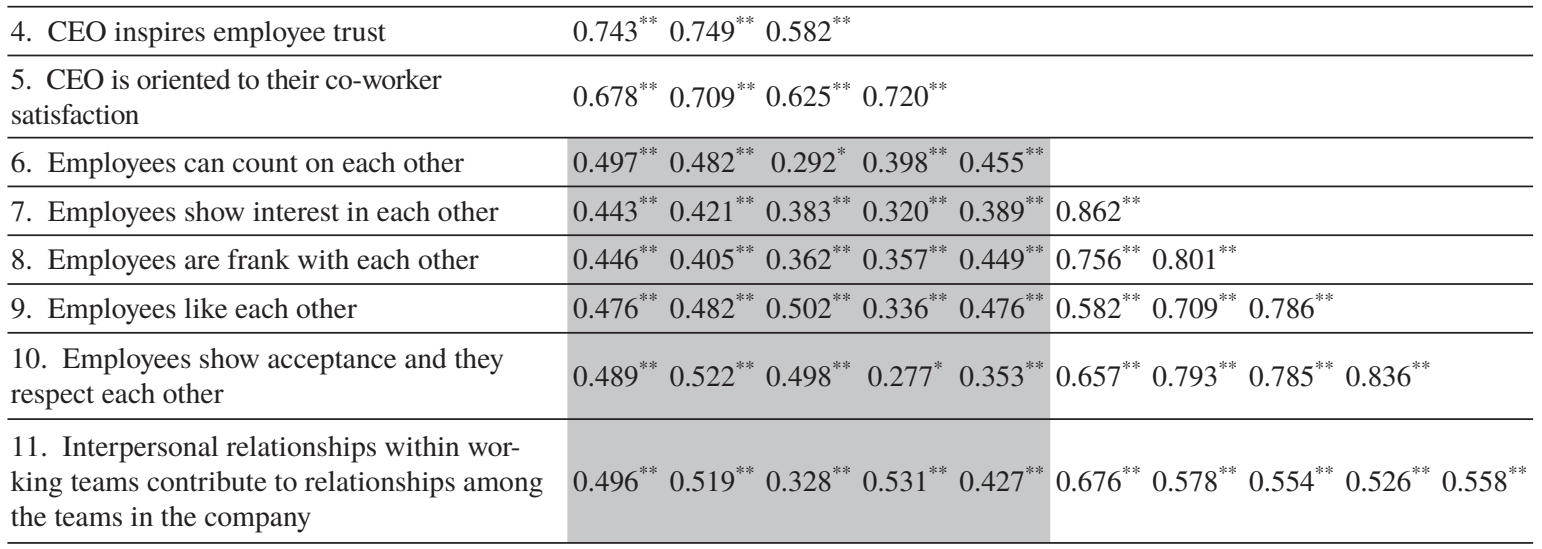

$\mathrm{N}=73$, Pearson correlation coefficient, ** correlation significant at level of 0.01 ; * correlation significant at level of 0.05

\section{Table 6.}

Correlations between the manifestations of leadership (top managers' behaviors) and interpersonal relationships in the Positive Organizational Potential context 
Table 6.

continued

\begin{tabular}{|c|c|c|c|c|c|c|c|c|c|c|c|c|}
\hline Variable & 1 & 2 & 3 & 4 & 5 & 6 & 7 & 8 & 9 & 10 & 11 & 12 \\
\hline \multicolumn{13}{|l|}{$\begin{array}{l}\text { 1. Managers perform leadership } \\
\text { roles in their teams }\end{array}$} \\
\hline $\begin{array}{l}\text { 2. Managers coordinate their } \\
\text { teams and foster relations }\end{array}$ & $0.844^{* *}$ & & & & & & & & & & & \\
\hline $\begin{array}{l}\text { 3. Managers perform coaching } \\
\text { roles in their teams }\end{array}$ & $0.760^{* *}$ & $0.811^{* *}$ & & & & & & & & & & \\
\hline $\begin{array}{l}\text { 4. Managers capture and disse- } \\
\text { minate information on business } \\
\text { goals and objectives }\end{array}$ & $0.690^{* *}$ & $0.759^{* * *}$ & $0.741^{* * *}$ & & & & & & & & & \\
\hline $\begin{array}{l}\text { 5. Managers initiate changes in } \\
\text { a company }\end{array}$ & $0.633^{* *}$ & $0.652^{* *}$ & $0.608^{* * *}$ & $0.678^{* *}$ & & & & & & & & \\
\hline \multicolumn{13}{|l|}{$\begin{array}{l}\text { 6. Through their behaviors, } \\
\text { mangers set a good example of } \\
\text { positive relations both within and } 0 . \\
\text { outside the team }\end{array}$} \\
\hline \multicolumn{13}{|c|}{$\begin{array}{l}\text { 7. Managers are oriented to self- } \\
\text {-development and increasing their } 0.653^{* *} 0.643^{* *} 0.613^{* *} 0.668^{* *} 0.719^{* *} 0.794^{* *} \\
\text { skills and competencies }\end{array}$} \\
\hline $\begin{array}{l}\text { 8. Employees can count on each } \\
\text { other }\end{array}$ & $0.554^{* *}$ & $0.539^{* *}$ & $0.567^{* * *}$ & $0.565^{* *}$ & $0.662^{* *}$ & $0.671^{* *}$ & $0.694^{* *}$ & & & & & \\
\hline $\begin{array}{l}\text { 9. Employees show interest in } \\
\text { each other }\end{array}$ & $0.477^{* *}$ & $0.502^{* *}$ & $0.505^{* *}$ & $0.500^{* *}$ & $0.561^{* *}$ & $0.680^{* *}$ & $0.597^{* *}$ & $0.862^{* *}$ & & & & \\
\hline $\begin{array}{l}\text { 10. Employees are frank with } \\
\text { each other }\end{array}$ & $0.478^{* *}$ & $0.435^{* *}$ & $0.502^{* *}$ & $0.470^{* *}$ & $0.607^{* *}$ & $0.687^{* *}$ & $0.577^{* *}$ & $0.756^{* *}$ & $0.801^{* *}$ & & & \\
\hline 11. Employees like each other & $0.455^{* *}$ & $0.457^{* *}$ & $0.410^{* *}$ & $0.458^{* *}$ & $0.493^{* *}$ & $0.666^{* *}$ & $0.516^{* *}$ & $0.582^{* *}$ & $0.709^{* *}$ & $0.786^{* *}$ & & \\
\hline $\begin{array}{l}\text { 12. Employees show acceptance } \\
\text { and they respect each other }\end{array}$ & $0.484^{* *}$ & $0.477^{* *}$ & $0.466^{* *}$ & $0.440^{* *}$ & $0.475^{* *}$ & $0.672^{* *}$ & $0.562^{* *}$ & $0.657^{* * *}$ & $0.793^{* *}$ & $0.785^{* *}$ & $0.836^{* *}$ & \\
\hline $\begin{array}{l}\text { 13. Interpersonal relationships } \\
\text { within working teams contribute } \\
\text { to relationships among the teams } \\
\text { in the company }\end{array}$ & $0.633^{* *}$ & $0.634^{* *}$ & $0.544^{* *}$ & $0.625^{* *}$ & $0.593^{* *}$ & $0.642^{* *}$ & $0.601^{* *}$ & $0.676^{* *}$ & $0.578^{* *}$ & $0.554^{* *}$ & $0.526^{* *}$ & $0.558^{* *}$ \\
\hline
\end{tabular}

Table 7.

Correlations between the manifestations of middle managers' behaviors and interpersonal relationships in the Positive Organizational Potential context 
THE ROLE OF LEADERSHIP IN SHAPING

Andrzej Lis Aldona Glińska-Neweś Magdalena Kalińska
The analysis of correlations between the manifestations of leadership (top managers' behaviors) and interpersonal relationships confirms the fact of moderate strengths between these two variables. The correlations between their manifestations range from $r=0.277$ ("CEO inspires employees trust" correlated with "employees show acceptance and they respect each other") to $r=0.531$ ("CEO inspires employees trust" correlated with "interpersonal relationships within working teams contribute to relationships among the teams in the company"). Among 30 correlations, only 4 of them are above $r=0.500$.

In comparison with top managers, the manifestations of middle managers' behaviors considered as a key area of Positive Organizational Potential are much strongly correlated with the manifestations of interpersonal relationships. The correlations range from $r=0.410$ ("managers perform coaching roles in their teams" correlated with "employees like each other") to $r=0.694$ ("managers are oriented to self-development and increasing their skills and competencies" correlated with "employees can count on each other"). Among all the manifestations of middle managers' behaviors, providing a model of positive relations both within and outside the team is the key correlate of interpersonal relationships manifestations. It correlates strongly with the following manifestations of interpersonal relationships: "employees are frank with each other" $(r=0.687)$, "employees show interest in each other" $(r=0.680)$, "employees show acceptance and they respect each other" $(r=0.672)$, "employees can count on each other" $(r=0.671)$. Analyzing correlations from the perspective of interpersonal relationships, the following manifestations are the most strongly correlated with middle managers' behaviors are "interpersonal relationships within working teams contributing to relationships among the teams in the company" and the fact that "employees can count on each other".

\section{Conclusion}

A Gallup survey reveals that managers are the main reason why employees leave their workplaces (Bono and Yoon, 2012). That proves a very special role played in organizations by employee relationships with their supervisors. At the same time, supervisory relationships as well as manager attitudes and skills influence and shape employee relationships with each other. The extent to which employees want to cooperate, their commitment and the quality of the social capital are affected by managers.

Summing up the study, leadership-related factors have been identified as the category of intra-organizational antecedents of a strong impact on interpersonal relationships. Such findings have been confirmed for the majority of studied intraorganizational antecedents related to leadership including: leaders' ability to influence and inspire others, models of relationships provided by both the top and middle managers, leaders' emphatic behaviors, treating subordinates with respect 
and building the climate of trust. The study of correlations between the key areas of Positive Organizational Potential has confirmed that interpersonal relationships are much stronger correlated with the attitudes and behaviors of middle managers than with those of top managers.

Our research contributes to the flow of analysis focused on the importance of employee immediate supervisors. According to the presented data, roles played by middle managers, particularly serving as an example of positive bonds, are significantly more important in forming employee relationships than the attitudes and behaviors of top managers. Nevertheless, both top and middle managers stimulate positive employee relationships if they act empathically and create themselves positive relations with others.

\section{Notes}

[1] Prof. Maria Romanowska, Ph.D. (Warsaw School of Economics), Prof. Jan Jeżak, Ph.D. (the University of Łódź); Prof. Małgorzata Czerska, Ph.D. (the University of Gdańsk), Prof. Czesław Sikorski, Ph.D. (the University of Łódź) and Prof. Janusz Strużyna, Ph.D. (the University of Economics in Katowice).

[2] Elżbieta Cabańska, MA (HR Director, Unilever Poland S.A.), Jacek Dymowski, PhD (CEO, Abadon Consulting, the author of the first Polish report complying with Global Reporting Initiative), Wojciech Grabowski, MBA (CEO, Hydro-Vacuum S.A.), Arkadiusz Krężel, MA (the former CEO of the Polish Agency for Enterprise Development, the chairman of the supervisory board of Impexmetal S.A.), Jarosław Józefowicz, MSc. (CEO, TZMO S.A.), Tomasz Modzelewski, Ph.D. (CEO, Zelmer Trading Sp. z o.o.), Bohdan Wyżnikiewicz, Ph.D. (vice-president, the Institute of Research on Market Economy) and Andrzej Zieliński, MA (HRM Director, NEUCA S.A.).

\section{References}

Allen, T.D., Turner de Tormes Eby, L. (2012), “The Study of Interpersonal Relationships: An Introduction", in: Turner de Tormes Eby, L., Allen T.D. (Eds.), Personal Relationships: The Effect on Employee Attitudes, Behavior, and Well-being, Routledge, New York, pp. 3-14.

Atwater, L., Carmeli, A. (2009), "Leader-Member Exchange, Feelings of Energy, and Involvement in Creative Work", Leadership Quarterly, Vol. 20 No. 3, pp. 264-275. DOI: http://www.dx.doi.org/10.1016/j.leaqua.2007.07.009

Avolio, B.J. (2011), Full Range Leadership Development, Sage Publications Inc., Thousand Oaks. DOI: http://www.dx.doi.org/10.4135/9781483349107

Avolio, B.J., Walumbwa F., Weber, T.J. (2009), "Leadership: Current Theories, Research, and Future Directions", Annual Reviews of Psychology, Vol. 60 No. 1, pp. 421-449. DOI: http://www.dx.doi.org/10.1146/annurev.psych.60.110707.163621

Bass, B.M. (1985), Leadership and Performance Beyond Expectations, The Free Press, New York.

Bass, B.M. (1990), Bass \& Stogdill's Handbook of Leadership: Theory, Research, and Managerial Applications, The Free Press, New York.

Bass, B.M. (1996), A New Paradigm of Leadership: An Inquiry into Transformational 
THE ROLE OF LEADERSHIP IN SHAPING

Andrzej Lis Aldona Glińska-Neweś Magdalena Kalińska
Leadership, U.S. Army Research Institute for the Behavioral and Social Sciences, Alexandria.

Bass, B.M., Avolio, B.J. (1990), "The Implications of Transactional and Transformational Leadership for Individual, Team, and Organizational Development”, in: Woodman R.W., Pasmore W.A. (Eds.), Research in Organizational Change and Development, JAI Press, Greenwich, pp. 231-272.

Bass, B.M., Avolio, B.J. (1993), “Transformational Leadership: A Response to Critiques", in: Chemers M.M., Ayman R. (Eds.), Leadership Theory and Research: Perspectives and Directions, Academic Press, San Diego, pp. 49-80.

Blustein, D.L. (2011), “A Relational Theory of Working”, Journal of Vocational Behavior, Vol. 79 No. 1, pp. 1-17. DOI: http://www.dx.doi.org/10.1016/j.jvb.2010.10.004

Bono, J.E., Yoon D.J. (2012), "Positive Supervisory Relationships", in: Turner de Tormes Eby, L., Allen, T.D. (Eds.), Personal Relationships: The Effect on Employee Attitudes, Behavior, and Well-being, Routledge, New York, pp. 43-66.

Cameron, K.S. (2012), Positive Leadership: Strategies for Extraordinary Performance, Berett-Koehler Publishers, San Francisco.

Cameron, K.S., Dutton, J.E., Quinn, R.E. (Eds.) (2003), Positive Organizational Scholarship: Foundations of a New Discipline, Berett-Koehler Publishers, San Francisco.

Cameron, K.S., Spreitzer G.M. (2012), "Introduction: What is Positive about Positive Organizational Scholarship?”, in: Cameron, K.S., Spreitzer, G.M. (Eds.), The Oxford Handbook of Positive Organizational Scholarship, Oxford University Press, New York, pp. 1-14.

Chiaburu, D.S., Harrison, D.A. (2008), "Do Peers Make the Place? Conceptual Synthesis and Meta-Analysis of Co-Worker Effects on Perceptions, Attitudes, OCBs, and Performance", Journal of Applied Psychology, Vol. 93, pp. 1082-1104.

Dansereau Jr., F., Graen, G., Haga, W.J. (1975), “A Vertical Dyad Linkage Approach to Leadership within Formal Organizations: A Longitudinal Investigation of the Role Making Process", Organizational Behavior and Human Performance, Vol. 13, pp. 46-78.

Dutton, J.E., Glynn, M. (2007), "Positive Organizational Scholarship", in: Cooper, C., Barling, J. (Eds.), Handbook of Organizational Behavior, Sage Publications Inc., Thousand Oaks, pp. 693-712.

Dutton, J.E., Heaphy, E.D. (2003), “The Power of High-Quality Connections", in: Cameron, K.S., Dutton, J.E., Quinn, R.E. (Eds.), Positive Organizational Scholarship. Foundation of a New Discipline, Berrett-Koehler Publishers, San Francisco, pp. 263-278.

Ehrenreich, B. (2009), Bright-sided: How Positive Thinking is Undermining America, Henry Holt, New York.

Eisenhardt, K.M., Kahwajy, J.L., Bourgeois III, L.J. (1997), "How Management Teams Can Have a Good Fight", Harvard Business Review, July-August, pp. 77-85.

Fiedler, F.E. (1964), "A Contingency Model of Leadership Effectiveness", in: Berkowitz L. (Ed.), Advances in Experimental Social Psychology, Vol. 1, pp. 149-190. DOI: http://www.dx.doi.org/10.1016/S0065-2601(08)60051-9

Floyd, S.W., Wooldridge, B. (1997), "Middle Management's Strategic Influence and Organizational Performance", Journal of Management Studies, Vol. 34 No. 3, pp. 465-485 
Gersick, C.J.G., Bartunek, J.M., Dutton, J.E. (2000), "Learning From Academia: The Importance of Relationships in Professional Life", Academy of Management Journal, Vol. 43 No. 6, pp. 1026-1044. DOI: http://www.dx.doi.org/10.2307/1556333

Glińska-Neweś, A. (2010), "Pozytywny Potencjał Organizacji jako prorozwojowa architektura zasobów przedsiębiorstwa", in: Stankiewicz M.J. (Ed.), Pozytywny Potencjat Organizacji: Wstęp do użytecznej teorii zarządzania, Dom Organizatora TNOiK, Toruń, pp. 37-52.

Glińska-Neweś, A. (2013), "Employee Interpersonal Relationships”, in: Stankiewicz, M.J. (Ed.), Positive Management: Managing the Key Areas of Positive Organisational Potential for Company Success, Dom Organizatora TNOiK, Toruń, pp. 125-154.

Graen, G.B., Uhl-Bien, M., (1998), “Development of Leader-member Exchange (LMX) Theory of Leadership over 25 Years: Applying a Multi-level Multi-domain Perspective”, Leadership Quarterly, Vol. 6 No. 2, pp. 219-247.

Granovetter, M. (1973), “The Strength of Weal Ties", American Journal of Sociology, Vol. 78 No. 6, pp. 1360-1380.

Grant, A.R., Parker, S.K. (2009), "Redesigning Work Design Theories: The Rise of Relational and Proactive Perspectives", Academy of Management Annals, Vol. 3 No. 1, pp. 317-375. DOI: http://www.dx.doi.org/10.1080/19416520903047327

Guth, W.D., Macmillan, I.C. (1986), "Strategy Implementation versus Middle Management Self-interest”, Strategic Management Journal, Vol. 7 No.4, pp. 313-327. DOI: http://www.dx.doi.org/10.1002/smj.4250070403

Haffer, R. (2013), "Mechanisms of the Key Positive Organizational Potential Areas Impact on Organizational Development", in: Stankiewicz, M.J. (Ed.), Positive Management: Managing the Key Areas of Positive Organisational Potential for Company Success, Dom Organizatora TNOiK, Toruń, pp. 287-316.

Halbesleben, J.R.B. (2012), "Positive Coworker Exchanges“, in: Turner de Tormes Eby, L., Allen, T.D. (Eds.), Personal Relationships: The Effect on Employee Attitudes, Behavior, and Well-being, Routledge, New York, pp. 107-130.

Ibarra, H. (1993), "Personal Networks of Women and Minorities in Management: A Conceptual Framework", Academy of Management Review, Vol. 18 No.1, pp. 56-87. DOI: http://www.dx.doi.org/10.2307/258823

Kahn, W.A. (1990), "Psychological Conditions of Personal Engagement and Disengagement at Work", Academy of Management Journal, Vol. 33 No. 4, pp. 692-724. DOI: http://www.dx.doi.org/10.2307/256287

Kahn, W.A. (1998), "Relational Systems at Work", in: Staw, B.M., Cummings, L.L. (Eds.), Research in Organizational Behavior, JAI Press, Greenwich, pp. 39-76.

Kahn, W.A., (2007), "Meaningful Connections: Positive Relationships and Attachments at Work", in: Dutton, J.E., Ragins, B.R. (Eds.), Exploring Positive Relationships at Work: Building a Theoretical and Research Foundation, Lawrence Erlbaum, New York, pp. 189-206.

Kalińska, M. (2013a), "Role menedżerów średniego szczebla w budowaniu pozytywnego potencjału organizacji”, Zarzadzanie i Finanse, Vol. 11 No. 4/2, pp. 155-169.

Kalińska M. (2013b), "Middle Managers in Creating Pro-developmental POP Outcomes", in: Stankiewicz, M.J. (Ed.), Positive Management: Managing the Key Areas of 
THE ROLE OF LEADERSHIP IN SHAPING

Andrzej Lis Aldona Glińska-Neweś Magdalena Kalińska
Positive Organisational Potential for Company Success, Dom Organizatora TNOiK, Toruń, pp. 89-123.

Karaszewski, R. (2010), "Rola przywództwa w kreowaniu Pozytywnego Potencjału Organizacji”, in: Stankiewicz, M.J. (Ed.), "Pozytywny Potencjał Organizacji: Wstęp do użytecznej teorii zarządzania", Dom Organizatora TNOiK, Toruń, pp. 253-277.

Karaszewski, R., Lis, A. (2013), “The Role of Leadership to Stimulate Pro-developmental Positive Organisational Potential”, in: Stankiewicz, M.J. (Ed.), Positive Management: Managing the Key Areas of Positive Organisational Potential for Company Success, Dom Organizatora TNOiK, Toruń, pp. 59-87.

Karaszewski, R., Lis, A. (2014), "Wewnątrzorganizacyjne uwarunkowania rozwoju pozytywnego potencjału organizacji”, in: Wachowiak, P., Winch, S. (Eds.), Granice w zarzadzaniu kapitatem ludzkim, SGH, Warszawa, pp. 183-198.

Luthans, F., Church, A.H. (2002), "Positive Organizational Behaviour: Developing and Managing Psycholgical Strengths", Academy of Management Executive, Vol. 16 No.1, pp. 57-72. DOI: http://www.dx.doi.org/10.5465/AME.2002.6640181

Mills, J., Clark, M.S. (1982), "Communal and Exchange Relationships", Review of Personality and Social Psychology, Vol. 3, pp. 121-144.

Peyrat-Guillard, D., Glińska-Neweś, A. (2010), "Positive Organizational Potential, Organizational Commitment and Organizational Citizenship Behavior: A French/Polish Comparison", Journal of Positive Management, Vol. 1 No. 1, pp. 47-64. DOI: http:// www.dx.doi.org/10.12775/JPM.2010.004

Ragins, B.R., Dutton, J.E. (2007). "Positive Relationships at Work: An Introduction and Invitation”, in: Dutton, J.E., Ragins, B.R. (Eds.), Exploring Positive Relationships at Work: Building a Theoretical and Research Foundation, Lawrence Erlbaum, New York, pp. 3-25.

Roberts, L.M. (2006), "Shifting the Lens on Organizational Life: The Added Value of Positive Scholarship", Academy of Management Review, Vol. 31 No. 2, pp. 292-305. DOI: http://www.dx.doi.org/10.5465/AMR.2006.20208681

Stankiewicz, M.J. (Ed.)(1999), Budowaniepotencjałukonkurencyjnościprzedsiębiorstwa: Stan $i$ kierunki rozwoju potencjału konkurencyjności polskich przedsiębiorstw w kontekście dostosowania gospodarki do wymogów Unii Europejskiej, Dom Organizatora TNOiK, Toruń.

Stankiewicz, M.J. (Ed.) (2002), Determinanty konkurencyjnościpolskich przedsiębiorstw: Sposoby i warunki umacniania konkurencyjności przedsiębiorstw $w$ perspektywie globalizacji gospodarki, Wydawnictwo UMK, Toruń.

Stankiewicz, M.J. (Ed.) (2010), Pozytywny Potencjał Organizacji: Wstęp do użytecznej teorii zarządzania, Dom Organizatora TNOiK, Toruń.

Stankiewicz, M.J. (Ed.) (2013a), Positive Management: Managing the Key Areas of Positive Organisational Potential for Company Success, Dom Organizatora TNOiK, Torun.

Stankiewicz, M.J. (2013b), "Mechanisms of Strategic Management of Key Positive Organizational Potential Areas - The Reference Model for Companies", in: Stankiewicz, M.J. (Ed.), Positive Management: Managing the Key Areas of Positive Organisational Potential for Company Success, Dom Organizatora TNOiK, Toruń, pp. 317-336. 
Stephens, J.P., Heaphy E., Dutton, J.E. (2012), "High Quality Connections", in: Cameron,

K.S., Spreitzer, G.M. (Eds.), The Oxford Handbook of Positive Organizational Scholarship, Oxford University Press, New York, pp. 385-399.

Stogdill, R. (1974), Handbook of Leadership, The Free Press, New York.

Uhl-Bien, M. (2003), "Relationship Development as a Key Ingredient for Leadership Development", in: Murphy, S.E., Riggio, R.E. (Eds.), The Future of Leadership Development, Lawrence Erlbaum Associates, Mahwah, pp. 129-1147.

Uhl-Bien, M. (2005), "Implicit Theories of Relationships in the Workplace", in: Schyns, B., Meindl, J.R., (Eds.), Implicit Leadership Theories: Essays and Explorations, Information Age Publishing, Greenwich, pp. 103-133.

Vroom, V.H., Yetton, P.W. (1973), Leadership and Decision-Making, University of Pittsburgh Press, Pittsburgh. 